\title{
ACADEMIC EVENTS FROM CONCEPTION TO FINAL REPORT: Report of experiences in university extension activities
}

\author{
Cláudia Araújo de Menezes Gonçalves Martinsa; \\ Sibelle da Silva Oliveirab; \\ Dorval Juan Cativo Carvalhoc.
}

\begin{abstract}
This study is characterized as a report of experience, based on the importance of university extension activities at events as a form of professional practice for students of the Tourism course of the State University of Amazonas - UEA. It reports on the results of an extension project entitled Academic Events from Conception to Final Report. The methodology used for the construction of this study consists of exploratory and descriptive research, qualitative in nature, with a bibliographic review to support the proposed discussion. In terms of the results of this experience, professional practice in the events sector is seen as the main factor contributing to the professional formation of students, through their involvement in more than forty events during the second half of 2017 and through to the end of 2018. The report is relevant because it inspires other colleges and universities to reproduce similar activities and even improve on them.
\end{abstract}

\section{KeYWORDS}

University extension;

Academic events;

Professional practice 


\section{INTRODUCTION}

The events segment, an important segment of the tourism industry, has a direct impact on the productive chain of a locality when it stimulates various types of services and products, seeking to cater for event delegates with quality and efficiency. The Ministry of Tourism (2010, p. 20) highlights that "when holding an event, it is important to understand the possible formats and the activities that best fit the proposal, and to ensure that they correspond to the demand of that event".

In this context, it is understood that an event is something that is planned in advance, aiming at its successful execution, as mistakes will have a negative impact on the image of the organizers. Matias (2004) outlines the main stages in the process of planning and organizing events: conception; pre-event; during the event itself, and post-event. It is recommended that each stage be implemented in a way that minimizes possible failures during the execution.

The events sector represents a great opportunity for the professional Tourismologist because it is one of the segments in which these professionals is trained to work. It is important to highlight that having a professional qualification provides a competitive differential in the sector, as the theoretical contribution to the acquisition of skills and techniques is essential, and can only be achieved through accredited shortor long-term courses. Practical experience is also indispensable, being a decisive moment and one of great responsibility, but this aspect is often inadequate within the academic universe. It was thinking about professional practice in events that the Escola Superior de Artes e Turismo - ESAT of the Universidade do Estado do Amazonas - UEA (School of Arts and Tourism of the State University of Amazonas in Brazil), implemented the extension project entitled Eventos Acadêmicos da Concepção ao Relatório Final (Academic Events from Conception to Final Report).

The results of the project were very satisfactory, especially for the team of students that benefited from the practical experience from 2017 to 2018 . This work is a report of experience that presents the results of project. However, it should be mentioned that the project is still in progress, with the team of participating students being renewed on a regular basis.

The methodology used in the construction of this report was based on Gil (2010), being configured as a qualitative research of exploratory and descriptive character, with a bibliographic methodological procedure. The events project, meanwhile, used the guidelines of Cesca (2008) as the methodology for its elaboration.

Besides the introduction, this report presents the work in five sections: 1. Research Question and Rele- vance, which describes important concepts for understanding the research; 2. The Methodology used in the construction of the report of experience and the extension project; 3. The Results, which describes the development of the project; 4. Practical implications and conclusions, highlighting opportunities for application of the central idea of the project by other institutions, and 5. References used.

\section{REseARCH QUESTION AND Rele- VANCE}

Working or conducting business in the events market requires a high level of professionalism among those who work, or intend to work in the sector. Matias (2004, p. 74) defines events as "professional action through research, planning, organization, coordination, control and implementation of a project, with the aim of reaching its target audience with concrete measures and projected results".

Oliveira (2013, p. 105) states that "the success of an event is closely related to the profile of those who organize it. Both quotations reinforce the importance of highly qualified professionals to stand out in the events sector. It is a sector with many amateurs, whose lack of professionalism often leads to failures. However, the possibilities are varied for those who seek professionalism and seek to excel in the events sector. The options range from short term professional courses to long-term courses through academic training, in addition to graduate studies.

The degree in Tourism is, therefore, a good option for those seeking self-improvement, as the events sector is one of the segments in which the tourist professional works. Through this course, tourism students will acquire all the necessary theoretical grounding to enable them to understand the dynamics of tourism and its multidisciplinary dialogue with many other areas of knowledge. However, it is should stressed that theoretical knowledge alone is not enough to work in the events sector. Practical experience is also essential, in order to understand its stages. This is the focus of this work, which addresses professional practice in events. In the case of the Tourism course of the Escola Superior de Artes e Turismo - ESAT of the Universidade do Estado do Amazonas - UEA, the students gain practical experience in events during the academic discipline of Events Planning and Organization. The course assessments are practical, giving students the chance to apply their knowledge. These practical activities help create, in those who identify with the area of events, a desire to know more, even after the end of the discipline. Thus, the following question emerged: How can tourism students be given professional practice in the events sector?

The answer to this question came through a proposed extension project in events, entitled: Eventos Acadêmicos da Concepçào ao Relatório Final (Academic Events from Conception to Final Report). Another factor that prompted the implementation of this Project was the narrative of teachers of the courses in music, dance 
and theater at the Escola Superior de Artes e Turismo ESAT in relation to the organization of their events, due to a lack of technical knowledge to carry out this task. The present project therefore aims to meet the needs mentioned above, as the academic extension activities allows students to go beyond scientific theoretical knowledge and the classroom environment and gain experience by putting into practice all the theoretical knowledge they have learned within the university. Castro (2004, p.14) emphasizes that "in the case of extension activities, what we see is that they produce knowledge through experience, giving them the capacity to narrate on their practice ".

Falcão (2006) emphasizes that academic extension activities are fundamental during this process of teachinglearning and research, allied with the practical experience that gives students the chance to participate more in the professional routines that they will perform in the future. According to the authors cited, it is understood that the students' experiences are based on their participation in entire transformative process between learning the theory and putting it into practice, and it is period in which they can learn from their mistakes, so as not to repeat them when they enter the job market. This is also true of the extension project that is being developed with the participation of students of the tourism course, to meet the demand for academic events of the ESAT. Therefore, the main objective of this work is to report the results of the extension project: Academic Events from Conception to Final Report. The importance of this study is that it addresses the students' experiences in the academic field, and that satisfactory results were obtained, both for the students involved in the project and for the teachers of the other courses, whose events were carried out successfully. Aiming to encourage professional practice for students through the development of extension projects, this work sets an example for other academic courses.

\section{METHODOLOGY}

According to Gil (2010), this study is characterized as qualitative, as it highlights peculiarities and complexities of the processes of planning, organizing and executing the academic events of this extension project.

Also based on Gil (2010), the research objectives in this report of experience are exploratory, as it investigates the topic in greater depth. It is also descriptive because it reports the experience gained through the execution of the events project. Gil (2010, p. 27) points out that "the majority of [studies] that are carried out with professional objectives probably fall into this category".

As for the technical procedures, the research was bibliographic. Gil (2010, p. 29) states that research "is developed based on already published material ". Therefore, books, magazines, articles, and journals were consulted, among other publications that addressed the topics of interest, such as events and extension projects aligned with professional practice.

\section{RESULTS}

The Bachelor of Tourism course of the ESAT, of the Universidade do Estado do Amazonas created, through its university extension, the project entitled Academic Events from Conception to Final Report, which has been running since 2015 . The target public for participation in the selection process consisted of students of the tourism course, with the aim of giving them experience of each phase in the planning and organization of events (conception; pre-event; during the event itself, and post-event) suggested by Matias (2004). The students were also able to use the practical experience to complete their compulsory hours of supervised internship.

It should be mentioned that project is still in progress, and that this work shares the results obtained with the team that took part from the second half of 2017 through to the end of 2018. During the period in question, the main partnership established for the project was with the Pro-Rectorate of Extension and Community Affairs - PROEX, which enabled a oneyear scholarship, as well as a grant to support the project. This grant was used to purchase materials, and uniforms so that the team could be easily identified when carrying out their duties at the events.

There were also other collaboration partnerships, such as the support provided by the Board of Directors of the ESAT for the provision of tables and chairs in the auditoriums; and with the and Post-Graduation Course in Management and Events Production, which provided the sound equipment, banner stands, and notebooks, among other items for use at the events. A partnership with the Laboratory of the Tourism course - LABOTUR, provided physical space for the team to plan events, hold meetings, and support for the material, among other activities.

As already mentioned, the idealization of the project arose out of two needs that were identified by the course coordinator; the main one was to provide professional practice in events for tourism students, in addition to what the course already offers; and the second arose out of the reports of teachers of other courses regarding the lack of technical knowledge to organize their events. Due to both situations, it was seen that on one hand, there was a demand, and on the other, there were students eager to put their knowledge into practice and provide the necessary labor.

Hence, the general objective of the project was to give tourism students an opportunity to apply the academic knowledge acquired throughout the course and to experience the routine practices of the tourism professional, by organizing academic events of the courses of the ESAT. Its specific objectives were: 
to create a structure for the academic events of the ESAT; to conduct research on competitive tenders for the submission of events requiring organizing; to create forms to standardize the activities; and to offer minicourses, lectures and training actions for those involved in the project, in relation to the events sector.

Some of these objectives were achieved. In relation to the structure for academic events, the project was incubated in the Tourism Laboratory - LABOTUR, in the Events/Planning and Tourism Management room, which has the necessary equipment and support for the development of activities, especially in the initial stages of registration of participants, meetings and training. It is also a place that provides support for the subsequent stages in the events planning and organization.

The research on competitive tenders for the submission of events was an objective that could not be achieved, because during the period in question, the Fundação de Amparo à Pesquisa de stado do Amazonas FAPEAM (Research Support Foundation of the State of Amazonas) suspended all types of competitive tender for events organization and support, greatly limiting the proponents' ability to promote themselves, and making this objective difficult to accomplish. This absence is one of the limitations of the project.

With the aim of standardizing the events project, the guidelines of Cesca's methodology (2008) were followed, which considers the items: 1 . Cover page; 2. Data; 3. Presentation of the event; 4 . Public of interest; 5 . Support from institutions and promotion; 6. Preliminary program; 7. Persons responsible and their functions; 8. Timeline; 9. Budget forecast; 10 . Forecast revenue; 11. Dissemination; 12. Evaluation; 13. Reports and 14. Annexes. In this case, the methodology had to be adapted to our reality. Therefore, a specific model was created for project events, which was used by all the participants to plan, organize and execute the events. These were then reviewed by the project coordinator. In regard to the training for those involved in the project, this was one of the first objectives to be achieved, because the activities begin with training, among many other activities that are carried out during the period of the project. Thus, the main objective of providing students with practical experience in events was successfully achieved.

In the second half of 2017, when the activities of the project were resumed, the initial experience took place at the ESAT itself, where the team organized eleven events. These are listed in Table 1 of the appendix to this work. One of the most interesting relationships was with the future artists of the dance, theatre and music courses. It was seen that these future artists are excellent performers, but that they have difficulty planning and organizing shows. This is where the tourism course was able to assist. And conversely, when the tourism course needed some artistic manifestation for its events, the art courses were always asked to step in. During the period of the study, it was seen that the team formed relationships between courses that led to greater interaction, establishing partnerships for future works.

In 2018, the project went beyond its proposed objective of supporting events only of the ESAT itself, and began to be sought out by other courses of the Universidade do Estado do Amazonas - UEA, which is multi-campus and has four other schools of higher education in the city. There was also demand from partner institutions. From there on, it began to provide support to external events, going beyond the university, and providing contact with other areas of knowledge, but always within the proposal of academic, scientific and cultural events. During this period, a total of thirty-six events were held. These are listed in Table 2 of the appendix to this work. The most surprising thing was how the project became known about, even without any advertising. It was discovered that the teachers of the university were chatting among themselves, mentioning the project and even recommending the team for support with events.

Thus, collating the information from Tables 1 and 2, in one and a half years of the project, a total of fortyseven events were held. This confirms that the proposal was successfully achieved, in terms of providing professional practice in events for students of tourism. There were also opportunities for paid internships in events, jobs in the area, and freelance work, in response to the students' excellent performance. At each event, participants reported their new and unique experiences of each event, the complexity in each stage, the teamwork, the professionalism, the flexibility in some situations, the responsibility in carrying out their activities and going beyond them, and most importantly, the certainty of being in the right profession.

In general, during the period studied, there were some situations where the events had already been planned by the event hosts. In these cases, the team acted only in the execution, setting up, welcoming, support for the speakers, and final disassembly, among other aspects. But there were also cases where the event hosts did not know where to start planning, and these cases, the team was involved in the entire event, from its conception through to the final report of the event.

The most evident characteristic of the experience was interdisciplinarity, based on the knowledge acquired during the course of Tourism, particularly the disciplines of Events Planning and Organization, and Gastronomy. The Events discipline provides all the theoretical support for planning, organization and execution, while the course in gastronomy assists during the cocktail of events, being indispensable for handling the catering. And during external events, there was collaboration with the courses in health, technology and education, among others. 
Given the importance of how the item organization was developed in a satisfactory way, motivating the participation of many other students in academic events, and also helping them towards approved papers in the form of expanded abstracts and scientific articles reporting their professional experience in the project. Regarding participation in national events, it is worth mentioning the 27th Brazilian Congress of Events Companies and Professionals, held by the Associação Brasileira de Empresas de Eventos - ABEOC (Brazilian Association of Events Companies), in the city of Rio de Janeiro from August 31st to September 2nd, 2017, in which defense of the expanded abstract was in 1st place among the 13 papers registered. Also, the participation in the 9th SeminTur Jr Meeting on November 8th, 2018, in the city of Caxias do Sul-RS, adding even more value and importance to the practice of the project during the defense of scientific papers.

The results far exceeded expectations, both of the project coordinator and the students, and of the events hosts, who consistently praised the team for the services provided, with such dedication. In 2019, the project was dedicated to conducting research, but it still provided support for some internal events.

\section{Practical Implications AND \\ Conclusions}

The project is unprecedented within the Universidade do Estado do Amazonas - UEA, being a pioneer, and it is already producing satisfactory results, with recognition from the Pro-Rectorate of Extension and Community Affairs - PROEX. It is considered innovative in the area of events, as there is no record of any other experience of this type that reconciles theory and practice in the city of Manaus, and it consolidates the threefold aims of the university: teaching, research and extension, leaving a positive mark on the academic lives of students, as some are already in employment, applying and expanding their practices.

The main impact of the extension project comes from the practical experience provided to the students involved, giving them more confidence in planning, organizing and executing academic events. It also helps them assume a new posture that will certainly bring efficiency and effectiveness to the professional experience; there is the teamwork, that enables new relationships to be built, an understanding of each stage to achieving success in the organization of events, and practice in the management of events that brought responsibility, autonomy and self-confidence in carryout out tasks of relevance to the tourismologist, as an event organizer.

The project created closer relationships between the university and the community, fulfilling the essential role of giving back to society, through the dissemination of knowledge, in response to the interest of the external public in participating in lectures, mini-courses, workshops, and other events that were open to the general public.

Another positive factor was the expansion of the effective competencies and skills that the students of tourism transmitted when executing the events for which their support was requested, also reverberating within the Academic Council of the Unit. The project received a Note of Gratitude from the Pro-Rectorate of Extension and Community Affairs - PROEX for its collaboration in the Voluntariado para Doação de Sangue (Blood Donation Volunteering) day, which was held for the first time in 2019.

In view of the results presented, this report aims to inspire other higher education institutions to carry out similar or even better work, fulfilling the offer of teaching, research and extension. It is recommended that new studies be conducted, to continue the work begun here.

\section{References}

BRASIL. Ministério do Turismo. Turismo de negócios e eventos: orientações básicas. Brasília: Ministério do Turismo, 2010.

CASTRO, Luciana Maria Cerqueira. A universidade, a extensão universitária e a produção de conhecimentos emancipadores. In: Reunião anual da ANPED, 27, Caxambu: Anais, 2004.

CESCA, Cleuza. G. Gimenes. Organização de Eventos: Manual para planejamento e execução. São Paulo: Summer, 2008.

FALCÃO, Emmanuel. Vivência em Comunidades: Outra Forma de Ensino. João Pessoa: Editora Universitária, 2006.

GIL, Antônio Carlos. Como elaborar projetos de pesquisa. 5. ed. São Paulo: Atlas, 2010.

MATIAS, Marlene. Organização de Eventos: procedimentos e técnicas. São Paulo: Manole, 2004.

OLIVEIRA, Marlene de. Organização e execução de eventos. Curitiba: e-Tec/MEC, 2013. 


\section{APPENDICES}

Table 1: List of events participated in during 2017

\begin{tabular}{|c|c|c|c|}
\hline No. & Event & Date & Place \\
\hline 1 & $\begin{array}{l}\text { PLANNING, ORGANIZATION, } \\
\text { EXECUTION AND FINAL RE- } \\
\text { PORT OF THE IX WEEK OF THE } \\
\text { ENVIRONMENT OF THE ESCO- } \\
\text { LA SUPERIOR DE ARTES E TU- } \\
\text { RISMO - ESAT (SCHOOL OF } \\
\text { ARTS AND TOURISM) }\end{array}$ & 06/05/2017 & ESAT \\
\hline 2 & $\begin{array}{l}\text { SUPPORT FOR THE PROJECT } \\
\text { IN THE LABOTUR: TRANSFOR- } \\
\text { MING GARBAGE DUMPS INTO } \\
\text { GARDENS }\end{array}$ & 06/10/2017 & $\begin{array}{l}\text { MINDU } \\
\text { SPRINGS } \\
\text { PARK }\end{array}$ \\
\hline 3 & $\begin{array}{l}\text { PLANNING, ORGANIZATION, } \\
\text { EXECUTION AND FINAL RE- } \\
\text { PORT OF THE III SUPERVISED } \\
\text { ESAT TRAINING SYMPOSIUM }\end{array}$ & 06/21/2017 & ESAT \\
\hline 4 & $\begin{array}{l}\text { SUPPORT FOR THE MEETING } \\
\text { FOR PLANNING, ORGANIZA- } \\
\text { TION AND EXECUTION OF } \\
\text { ESAT INSTITUTIONAL EVENTS }\end{array}$ & 07/03/2017 & ESAT \\
\hline 5 & $\begin{array}{l}\text { SUPPORT FOR THE NATIONAL } \\
\text { SEMINAR ON THEATRICAL } \\
\text { DIRECTION }\end{array}$ & 08/18/2017 & ESAT \\
\hline 6 & $\begin{array}{l}\text { SUPPORT FOR THE II NATIO- } \\
\text { NAL SEMINAR ON THEATRI- } \\
\text { CAL DIRECTION }\end{array}$ & 09/11/2017 & ESAT \\
\hline 7 & $\begin{array}{l}\text { SUPPORT TOURISM WEEK } \\
\text { OFFERING LECTURES TO THE } \\
\text { COMMUNITY }\end{array}$ & $\begin{array}{l}\text { From } 09 / 25 \\
\text { to } \\
09 / 30 / 2017\end{array}$ & ESAT \\
\hline 8 & $\begin{array}{l}\text { PLANNING, ORGANIZATION, } \\
\text { EXECUTION AND FINAL RE- } \\
\text { PORT OF THE III AMAZON } \\
\text { CHORAL FESTIVAL }\end{array}$ & $\begin{array}{l}\text { From } \\
09 / 28 / 2017 \\
\text { to } \\
10 / 01 / 2017\end{array}$ & $\begin{array}{l}\text { VARIOUS } \\
\text { AUDITO- } \\
\text { RIUMS }\end{array}$ \\
\hline 9 & $\begin{array}{l}\text { SUPPORT FOR THE 3RD NATI- } \\
\text { ONAL SEMINAR OF THEATRI- } \\
\text { CAL DIRECTION }\end{array}$ & $10 / 06 / 2017$ & ESAT \\
\hline 10 & 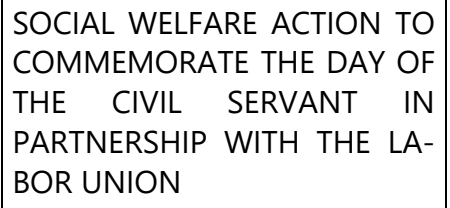 & 10/30/2017 & EST \\
\hline 11 & $\begin{array}{l}\text { SUPPORT FOR THE PROJECT } \\
\text { INCUBATED IN THE LABOTUR: } \\
\text { TRANSFORMING GARBAGE } \\
\text { DUMPS INTO GARDENS }\end{array}$ & 12/09/2017 & $\begin{array}{l}\text { MINDU } \\
\text { SPRINGS } \\
\text { PARK }\end{array}$ \\
\hline
\end{tabular}

Table 2: List of events participated in during 2018

\begin{tabular}{|c|c|c|c|}
\hline o. & Event & Date & Place \\
\hline 1 & $\begin{array}{l}\text { SUPPORT FOR THE EVENT: } \\
\text { SEMINAR ON MANAGEMENT } \\
\text { OF WATER RESOURCES OF } \\
\text { AMAZONAS }\end{array}$ & $03 / 05 / 2018$ & EST \\
\hline 2 & $\begin{array}{l}\text { SUPPORT FOR THE EVENT: } \\
\text { COMMUNITY GARDEN CLEA- } \\
\text { NING TASK FORCE }\end{array}$ & $03 / 17 / 2018$ & $\begin{array}{l}\text { MINDU } \\
\text { SPRINGS } \\
\text { PARK }\end{array}$ \\
\hline 3 & $\begin{array}{l}\text { SUPPORT FOR THE EVENT: } \\
\text { OPERATIONALIZATION OF } \\
\text { THE DEBATE ON ELECTIONS } \\
\text { FOR THE RECTORATE }\end{array}$ & $03 / 21 / 2018$ & ESAT \\
\hline 4 & $\begin{array}{l}\text { SUPPORT FOR THE EVENT: IV } \\
\text { ABRAÇO SIMBÓLICO NO IGA- } \\
\text { RAPÉ DO MINDU [IV SYMBO- } \\
\text { LIC HUG AT } \\
\text { STREAM] }\end{array}$ & $03 / 22$ & $\begin{array}{l}\text { MINDU } \\
\text { SPRINGS } \\
\text { PARK }\end{array}$ \\
\hline 5 & $\begin{array}{l}\text { SUPPORT FOR THE EVENT: I } \\
\text { SEMINAR OF THE THEATER OF } \\
\text { AMAZONAS }\end{array}$ & $\begin{array}{c}\text { From } \\
03 / 27 / 2019 \\
\text { to } \\
03 / 29 / 2018\end{array}$ & $\begin{array}{l}\text { PALACE } \\
\text { OF JUS- } \\
\text { TICE }\end{array}$ \\
\hline 6 & $\begin{array}{l}\text { TRAINING WITH VOLUNTEER } \\
\text { INTERNS }\end{array}$ & $\begin{array}{l}04 / 05 / 2017 \\
\text { and } \\
04 / 06 / 2018\end{array}$ & ESAT \\
\hline 7 & $\begin{array}{l}\text { PLANNING, ORGANIZATION } \\
\text { AND EXECUTION OF THE LEC- } \\
\text { TURE SELF-KNOWLEDGE AS A } \\
\text { COMPETITIVE DIFFERENTIAL } \\
\text { IN THE PROFESSIONAL CARE- } \\
\text { ER }\end{array}$ & 04/06/2018 & ESAT \\
\hline 8 & $\begin{array}{l}\text { PLANNING, ORGANIZATION } \\
\text { AND EXECUTION OF MEETING } \\
\text { DIALOGUES AND REFLEC- } \\
\text { TIONS ON THE IMPLEMENTA- } \\
\text { TION OF THE BNCC IN AMA- } \\
\text { ZONAS }\end{array}$ & $04 / 1$ & ESAT \\
\hline 9 & $\begin{array}{l}\text { SUPPORT FOR THE EVENT: } \\
\text { ESCOLA SÉCULO: ERA UMA } \\
\text { VEZ O FUTURO [SCHOOL SÉ- } \\
\text { CULO: ONCE UPON A TIME } \\
\text { THERE WAS THE FUTURE] }\end{array}$ & $04 / 2$ & $\begin{array}{l}\text { CENTURY } \\
\text { SCHOOL }\end{array}$ \\
\hline 10 & $\begin{array}{l}\text { PLANNING, ORGANIZATION, } \\
\text { EXECUTION AND FINAL RE- } \\
\text { PORT OF THE SHAKESPEARE } \\
\text { LECTURE }\end{array}$ & 04/27/2018 & \begin{tabular}{|l} 
THEATER \\
COFFEE
\end{tabular} \\
\hline 11 & $\begin{array}{l}\text { PLANNING, ORGANIZATION, } \\
\text { EXECUTION AND FINAL RE- } \\
\text { PORT OF THE 5TH FEIRA CRI- } \\
\text { ATIVA [CREATIVE FAIR] }\end{array}$ & 05/05/2018 & $\begin{array}{l}\text { USINA } \\
\text { CHAMI- } \\
\text { NÉ }\end{array}$ \\
\hline
\end{tabular}




\begin{tabular}{|c|c|c|c|}
\hline 12 & $\begin{array}{l}\text { SUPPORT FOR THE EVENT: } \\
\text { MARIA HELENA FONSECA } \\
\text { TOURISM AWARD }\end{array}$ & 05/09/2018 & ESAT \\
\hline 13 & $\begin{array}{l}\text { PROPOSITION, PLANNING, } \\
\text { ORGANIZATION, EXECUTION } \\
\text { OF THE EVENT VISA ACADÉ- } \\
\text { MICA: PRIEIROS PASSOS } \\
\text { [ACADEMIC LIFE: FIRST } \\
\text { STEPS], FOR WHICH THE TAR- } \\
\text { GET AUDIENCE WAS THE } \\
\text { FIRST PERIODS OF THE TOU- } \\
\text { RISM COURSE }\end{array}$ & 05/10/2018 & ESAT \\
\hline 14 & $\begin{array}{l}\text { SUPPORT FOR THE EVENT: } \\
\text { LANÇAMENTO LIVRO PLANE- } \\
\text { JAMENTO DE TRILHAS [BOOK } \\
\text { LAUNCH PLANNING TRAILS] }\end{array}$ & 05/12/2018 & $\begin{array}{l}\text { PROVIN- } \\
\text { CIAL PA- } \\
\text { LACE }\end{array}$ \\
\hline 15 & $\begin{array}{l}\text { PLANNING, ORGANIZATION } \\
\text { AND EXECUTION OF THE IV } \\
\text { MEETING OF THE COMMU- } \\
\text { NITY FOR THE PRACTICE OF } \\
\text { VISITING PROTECTED AREAS }\end{array}$ & $\begin{array}{l}\text { From } \\
05 / 16 / 2018 \\
\text { to } \\
05 / 18 / 2018\end{array}$ & CAUA \\
\hline 16 & $\begin{array}{l}\text { PLANNING, ORGANIZATION } \\
\text { AND EXECUTION OF THE V } \\
\text { INTERNATIONAL SYMPOSIUM } \\
\text { OF IBERO AMERICAN MUSIC }\end{array}$ & $\begin{array}{l}\text { From } \\
05 / 21 / 2018 \\
\text { to } \\
05 / 25 / 2018\end{array}$ & ESAT \\
\hline 17 & \begin{tabular}{|lrl} 
PLANNING, & ORGANIZING \\
AND EXECUTING THE I MUNI- \\
CIPAL SEMINAR ON PRO- \\
PHYLAXIX OF VERTICAL \\
TRANSMISSION OF HIV, \\
\multicolumn{3}{l}{ SYPHILIS AND HEPATITIS }
\end{tabular} & $\begin{array}{l}05 / 24 / 2018 \\
\text { and } \\
05 / 25 / 2018\end{array}$ & $\begin{array}{l}\text { LUIZ } \\
\text { MONTE- } \\
\text { NEGRO } \\
\text { AUDITO- } \\
\text { RIUM }\end{array}$ \\
\hline 18 & $\begin{array}{l}\text { PLANNING, ORGANIZATION } \\
\text { AND EXECUTION OF THE IV } \\
\text { ESAT TRAINING SYMPOSIUM }\end{array}$ & 06/09/2018 & ESAT \\
\hline 19 & $\begin{array}{l}\text { PLANNING, ORGANIZING } \\
\text { AND EXECUTION OF THE TCC } \\
\text { WORKSHOP }\end{array}$ & 06/11/2018 & ESAT \\
\hline 20 & $\begin{array}{l}\text { V SCIENTIFIC SEMINAR OF } \\
\text { THE POSTGRADUATE PRO- } \\
\text { GRAM IN LETTERS AND ARTS } \\
\text { (PPGLA) }\end{array}$ & $\begin{array}{l}\text { From } \\
06 / 12 / 2018 \\
\text { to } \\
06 / 15 / 2018\end{array}$ & ESAT \\
\hline 21 & $\begin{array}{l}\text { SUPPORT FOR THE EVENT: } \\
\text { SBPC SEMINAR QUAL O FU- } \\
\text { TURO DA CIÊNCIA NO AMA- } \\
\text { ZONAS [WHAT IS THE FUTURE } \\
\text { OF SCIENCE IN THE AMA- } \\
\text { ZON?] }\end{array}$ & 06/14/2018 & $\begin{array}{l}\text { PLAZA } \\
\text { MUSA }\end{array}$ \\
\hline 22 & $\begin{array}{l}\text { SUPPORT FOR THE EVENT: } \\
\text { 1ST MEETING OF THE YOUNG } \\
\text { SANITATION PROFESSIONALS } \\
\text { (JPS) OF THE AMAZON }\end{array}$ & $05 / 15 / 2018$ & EST \\
\hline 23 & $\begin{array}{l}\text { PLANNING, ORGANIZING } \\
\text { AND EXECUTING THE FORUM } \\
\text { OF DANCE COORDINATORS }\end{array}$ & $\begin{array}{l}06 / 18 / 2018 \\
\text { and } \\
06 / 19 / 2018\end{array}$ & $\begin{array}{l}\text { PALACE } \\
\text { OF JUS- } \\
\text { TICE }\end{array}$ \\
\hline
\end{tabular}

\begin{tabular}{|c|c|c|c|}
\hline 24 & $\begin{array}{l}\text { V NATIONAL CONGRESS OF } \\
\text { DANCE RESEARCHERS OF THE } \\
\text { ASSOCIAÇÃO NACIONAL DE } \\
\text { PESQUISADORES EM DANÇA } \\
\text { (NATIONAL ASSOCIATION OF } \\
\text { DANCE RESEARCHERS) - AN- } \\
\text { DA: } 10 \text { YEARS }\end{array}$ & $\begin{array}{c}\text { From } \\
06 / 20 / 2018 \\
\text { to } \\
06 / 23 / 2018\end{array}$ & ESAT \\
\hline 25 & $\begin{array}{l}\text { PLANNING, ORGANIZATION } \\
\text { AND EXECUTION OF THE FES- } \\
\text { TA JUNINA [TRADITIONAL } \\
\text { JUNE FESTIVAL] OF ESAT }\end{array}$ & 06/21/2018 & ESAT \\
\hline 26 & $\begin{array}{l}\text { PLANNING, ORGANIZATION } \\
\text { AND EXECUTION OF THE } \\
\text { COMMUNITY } \\
\text { CLEANING TASK FORCE }\end{array}$ & $06 / 29 / 2018$ & $\begin{array}{l}\text { MINDU } \\
\text { SPRINGS } \\
\text { PARK }\end{array}$ \\
\hline 27 & $\begin{array}{l}\text { SUPPORT FOR THE EVENT: } \\
\text { TECHNICAL VISIT TO THE SCI- } \\
\text { ENCE FOREST OF THE DIO- } \\
\text { FANTO MONTEIRO STATE } \\
\text { SCHOOL }\end{array}$ & 08/24/2018 & $\begin{array}{l}\text { FOREST } \\
\text { OF SCI- } \\
\text { ENCE }\end{array}$ \\
\hline 28 & $\begin{array}{l}\text { PLANNING, ORGANIZATION } \\
\text { AND EXECUTION OF THE } \\
\text { AMAZONIAN MANAGEMENT } \\
\text { SYMPOSIUM - AMAS }\end{array}$ & $\begin{array}{l}\text { From } \\
08 / 29 / 2019 \\
\text { to } \\
08 / 31 / 2018\end{array}$ & $\begin{array}{l}\text { VASCO } \\
\text { VASQUES } \\
\text { CON- } \\
\text { VENTION } \\
\text { CENTER }\end{array}$ \\
\hline 29 & $\begin{array}{l}\text { PLANNING, ORGANIZATION } \\
\text { AND EXECUTION OF THE II } \\
\text { SEMINAR OF THE NORTH } \\
\text { REGION: EDUCATION, ART } \\
\text { AND INTERCULTURE }\end{array}$ & $\begin{array}{l}\text { From } \\
09 / 13 / 2018 \\
\text { to } \\
09 / 15 / 2018\end{array}$ & ESAT \\
\hline 30 & $\begin{array}{l}\text { EVENT SUPPORT: FEIRA NOR- } \\
\text { TE DO ESTUDANTE [NORTH } \\
\text { STUDENT FAIR] }\end{array}$ & $\begin{array}{l}\text { From } \\
09 / 26 / 2018 \\
\text { to } \\
09 / 28 / 2018\end{array}$ & $\begin{array}{l}\text { PLAZA } \\
\text { SHOP- } \\
\text { PING }\end{array}$ \\
\hline 31 & $\begin{array}{l}\text { PLANNING, ORGANIZATION } \\
\text { AND EXECUTION OF THE } \\
\text { AMAZONAS CHOIR FESTIVAL } \\
\text { - FAMCOR }\end{array}$ & $\begin{array}{l}\text { From } \\
09 / 26 / 2018 \\
\text { to } \\
09 / 28 / 2018\end{array}$ & $\begin{array}{l}\text { VARIOUS } \\
\text { AUDITO- } \\
\text { RIUMS }\end{array}$ \\
\hline 32 & $\begin{array}{l}\text { PLANNING, ORGANIZATION } \\
\text { AND EXECUTION IN THE PRE- } \\
\text { SENTATION OF THE ORCHES- } \\
\text { TRAS AND YOUTH BANDS } \\
\text { (UEA ORCHESTRA) PROJECT }\end{array}$ & $10 / 24 / 2018$ & $\begin{array}{l}\text { INSTAL- } \\
\text { LATION } \\
\text { THEATER }\end{array}$ \\
\hline 33 & $\begin{array}{l}\text { PLANNING, ORGANIZING } \\
\text { AND IMPLEMENTATION OF } \\
\text { THE COMMON NATIONAL } \\
\text { CURRICULAR BASE AND THE } \\
\text { TEACHING OF THE ARTS: } \\
\text { CURRENT PERSPECTIVES }\end{array}$ & $10 / 31 / 2018$ & ESAT \\
\hline 34 & $\begin{array}{l}\text { PLANNING, ORGANIZATION } \\
\text { AND EXECUTION OF THE IN- } \\
\text { NOVATION AND ENTREPRE- } \\
\text { NEURSHIP MEETING }\end{array}$ & $11 / 22 / 2018$ & ESAT \\
\hline
\end{tabular}




\begin{tabular}{|c|c|c|c|}
\hline 35 & $\begin{array}{l}\text { PLANNING, ORGANIZATION } \\
\text { AND EXECUTION OF THE END } \\
\text {-OF-YEAR CONCERT OF STU- } \\
\text { DENTS OF THE EXTENSION } \\
\text { COURSE OF BASIC TRAINING } \\
\text { IN MUSIC OF THE UEA }\end{array}$ & $12 / 08 / 2018$ & $\begin{array}{l}\text { CULTU- } \\
\text { RAL CEN- } \\
\text { TER RIO } \\
\text { NEGRO } \\
\text { PALACE }\end{array}$ \\
\hline 36 & $\begin{array}{l}\text { SUPPORT FOR THE EVENT: } \\
\text { 4TH SALÃO DE TURISMO } \\
\text { AMAZONAS [AMAZONAS } \\
\text { TOURISM SHOWCASE] }\end{array}$ & $\begin{array}{l}12 / 21 / 2018 \\
\text { and } \\
12 / 22 / 2018\end{array}$ & $\begin{array}{l}\text { VASCO } \\
\text { VASQUES } \\
\text { CON- } \\
\text { VENTION } \\
\text { CENTER }\end{array}$ \\
\hline
\end{tabular}

Source: Prepared by the authors (2019). 